BIBECHANA

Vol. 6, March 2010

\title{
BIO-DIVERSITY CONSERVATION IN NEPAL
}

\author{
D. Thapa \\ P.G. Campus, Biratnagar, Tribhuvan University, Nepal
}

\begin{abstract}
The importance of biodiversity has been explained with examples. The effort applied for the conservation of biodiversity in Nepal has been studied. I have also presented the species which are legally protected by the Nepal government.
\end{abstract}

Keywords: biodiversity; wildlife reserves; aquatic animals

\section{Introduction}

Bio-diversity means simply the different life forms or varieties of life. The care and management of biological things is called bio-diversity conservation.

Bio-diversity conservation is one of the most important global responsibilities of the mankind to ensure its safe future. Hence the United Nations Conference on Environment and Development (UNCED) has given a prime importance on the agenda of bio-diversity conservation to the Earth Summit held in Rio-de Jenerio in June 1992. Nepal has great diversity of flora and fauna due to unique geographical location with representative of deciduous and coniferous forests of subtropical and temperate regions to the sub-alpine and alpine, pastures and snow capped Himalayan peaks with their cold streams, glaciers and lakes.

\section{Conservation of biodiversity}

Nepal consist more than 5,000 species of flowering plants, 181 species of mammals, 844 species of birds, 185 species of fishes, about 635 species of butterflies and more than 2252 moths.

The concept of bio-diversity conservation was arisen in Rana regime when the central zoo was established in Nepal. However, the active efforts for the conservation of bio-diversity started about 30 years ago. Nowadays, many efforts have been applied for the conservation of biodiversity. The various efforts include protected areas, zoo, different types of law, conventions, non governmental organizations (NGOs), local and national authorities, national and international organizations, etc. Among them the protected areas is main. The protected areas conserve the biological things in their original place which is called in situ conservation.

The protected areas has covered 26,695 km. square (18.32\%) of the total area of Nepal. The National Parks and Wildlife Conservation Act 1973 provides the legal basis for the management of protected areas. The protected areas include nine national parks, three wildlife reserves, one hunting reserve, three conservation areas and six buffer zones.

\section{Protected areas}

\section{National Park}

National park is an area set up for the conservation and management flora and fauna, landscapes, and historic objects of an area. The activities like hunting and damaging any animal, grazing, cultivation, felling any tree are prohibited within the national park's area. 
D. Thapa

\section{Wildlife Reserve}

It is an area set aside for the conservation and management of animals and plants in their habitat.

\section{Conservation Area}

It is an area managed with an integrated plan for the conservation of natural environment and the sustainable use of natural resources.

\section{Hunting Reserve:}

It is an area set aside for the conservation and management of wildlife. It provides legal hunting opportunity.

\section{Buffer Zone:}

It is a surrounding area of national park and wildlife reserve. The local people can use this zone for collection of forest products.

\section{Protected Areas of Nepal}

Table 1 (National Parks)

\begin{tabular}{|c|l|c|c|}
\hline S.N. & Category and Name (year of establishment) & Area (km s. q.) & Altitude (m) \\
\hline 1 & Royal Chitwan National Park (1973) & 932 & $150-815$ \\
\hline 2 & Royal Bardia National Park (1976\1988) & 968 & $152-1494$ \\
\hline 3 & Shavipuri National Park (2002) & 144 & $1366-2732$ \\
\hline 4 & Khaptad National Park (1984) & 225 & $1000-3276$ \\
\hline 5 & Makalu Barun National Park (1991) & 1500 & $435-8463$ \\
\hline 6 & Sagarmatha National Park (1976) & 1148 & $2800-8850$ \\
\hline 7 & Langtang National Park (1976) & 1710 & $792-7245$ \\
\hline 8 & Shey Phoskundo National Park (1984) & 3555 & $2000-6885$ \\
\hline 9 & Rara National Park (1976) & 106 & $1800-4048$ \\
\hline \multicolumn{2}{|r|}{ Total } & 10288 & \\
\hline
\end{tabular}

Table 2 (Wildlife Reserves)

\begin{tabular}{|c|l|c|c|}
\hline S.N. & Category and Name (year of establishment) & Area (km s.q.) & Altitude (m) \\
\hline 1 & Koshi Tappu Wildlife Reserve (1976) & 175 & 90 \\
\hline 2 & Parsa Wildlife Reserve (1984) & 499 & $150-815$ \\
\hline 3 & Royal Shuklaphanta Wildlife Reserve (1976) & 305 & $90-270$ \\
\hline \multicolumn{2}{|r|}{ Total } & 979 & \\
\hline
\end{tabular}


BIBECHANA

Vol. 6, March 2010

Table 3 (Hunting Reserve)

\begin{tabular}{|c|l|c|c|}
\hline S.N. & Category and Name (year of establishment) & Area (km s.q.) & Altitude (M) \\
\hline 1 & Dhorpatan Hunting Reserve & 1325 & $700-2850$ \\
\hline \multicolumn{2}{|r|}{ Total } & 1325 & \\
\hline
\end{tabular}

Table 4 (Conservation Areas)

\begin{tabular}{|c|l|c|c|}
\hline S.N. & Category and Name (year of establishment) & Area (km s.q.) & Altitude (m) \\
\hline 1 & Kanchanjunga Conservation Area (1997) & 2035 & $1200-8598$ \\
\hline 2 & Mansalu Conservation Area (1998) & 1663 & $1360-8163$ \\
\hline 3 & Annapurna Conservation Area (1986\1992) & 7629 & $1000-8082$ \\
\hline \multicolumn{2}{|r|}{ Total } & 11327 & \\
\hline
\end{tabular}

Table 5 (Buffer zones)

\begin{tabular}{|c|l|c|}
\hline S.N. & \multicolumn{1}{|c|}{ Buffer zones } & Area (km s.q.) \\
\hline 1 & Royal Chitwan National Park & 750 \\
\hline 2 & Royal Bardia National Park & 328 \\
\hline 3 & Makalu Barun National Park & 830 \\
\hline 4 & Langtang National Park & 420 \\
\hline 5 & Shey Phoskundo National Park & 449 \\
\hline 6 & Sagarmatha National Park & 275 \\
\hline \multicolumn{2}{r|}{ Total Protected Area of Nepal } & 3051 \\
\hline \multicolumn{2}{r|}{$\%$ of Nepal Territory } & $(18.32)$ \\
\hline
\end{tabular}

The protected areas helping to conserve medicinal, fodder, timber and other threatened plants along with wild rare, endangered animals etc.

\section{Rules and regulation for the conservation of biodiversity}

Zoo is another important tool for the protection of threatened animals. The National Zoo of Nepal which is situated in Kathmandu is helping for the conservation of important animals from different ecological zones of the country. Notable animals are rhino, tiger, crocodile, black bear, Black buck, clouded leopard etc.

For the conservation of biodiversity, many rules (acts) and regulations has been formed by the government of Nepal. Some of them are:

Aquatic Animals Protection Act (1961): it is concerned for the protection of wetlands and aquatic animals. 


\section{Thapa}

National Parks and Wildlife Conservation Act (1973): It is the base for the management of protected areas.

The other important acts which are helping directly and indirectly for the conservation of biodiversity like Forest Act (1993), Environmental Protection Act (1996), Soil and Watershed Conservation Act (1982), Water Resource Act (1992), Electricity Act (1992), Livestock Health and Livestock Service Act (1998). The regulations includes Himalayan National Park Regulations (1979), Buffer Zone Management Regulations (1996), Environmental Protection Regulations (1997) etc. These regulations are also concerned for the protection of biodiversity.

Similarly, Environment Protection Council (1992), Ministry of Forest and Soil Conservation, Ministry of Agriculture, Ministry of Population and Environment, National Planning Commission, National Agriculture Research Council, Nepal Academy of Science and Technology, Department of Botany and Zoology of Tribhuvan University, local authorities (Village Development Committee and District Development Committee) are working for the conservation of biodiversity.

Non government organizations like Ecological Society (ECOS), Natural History Society of Nepal (NASHON), Legal and Environmental Analysis for Development and Research Service (LEADERS) are also working directly and indirectly for the conservation of biodiversity in Nepal.

The international conventions like the World Heritage Convention (1992), Convention on International Trade in Endangered Species of Fauna and Flora (CITES),1993, Ramsar Convention on Wetlands of International Importance (1971), Convention on Biological Diversity (1992) are also related for the conservation of biodiversity.

There are also many international and national organizations which are working on biodiversity research and conservation. Some of them are followings:

1) International Union for the Conservation of Nature (IUCN)

2) United Nations Environmental Programme (UNEP).

3) World Wildlife Fund (WWF).

4) Global Environmental Facility (GEF)

5) International Centre for Integrated Mountain Development (ICIMOD)

6) International Plant Genetic Resource Institute (IPGRI)

7) King Mahendra Trust for Nature Conservation (KMTNC).

The Government of Nepal has given legal protection to 27 mammal species, 9 bird species, and three reptile species under the National Park and Wildlife Conservation Act 1973. The protected animals are listed in Table 6, 7, and 8.

The Government of Nepal has protected many plant species under the Forest act 1993. The Juglans regia (Bark of tree), Picrorhiza kurroa (Kutki), etc, are banned for collection, use, sale and distribution, transportation and export. The other important medicinal plants like Valeriana jatamansi (Jatamansi), Rauvolfia serpentina (sarpagandha), Abies spectabilis (Talis patra), Taxus baccata (Lauth salla), Cordyceps sinensis (Yarsagumba) are banned for export except processed and permission of department of forest. Similarly, Michelia champaca (Champ), Acacia catechu (Khayer), shorea rubusta (sal, Sakhuwa), Bombax malabaricum (Simal), Dalbergia latifolia (Satisal), Pterocarpus marsupium (Bijayasal), etc, are banned for transportation, export and felling for commercial purposes. 
BIBECHANA

Vol. 6, March 2010

Table 7- Protected Birds of Nepal

\begin{tabular}{|c|l|l|}
\hline S.N. & \multicolumn{1}{|c|}{ English name } & \multicolumn{1}{c|}{ Scientific name } \\
\hline 1 & Gaint Hornbill & Buceros bicornis \\
\hline 2 & Cheer Pheasant & Catreus wallichii \\
\hline 3 & Bengal Florican & Hubaropsis bengalensis \\
\hline 4 & Impeyon pheasant & Lophophorus impejanus \\
\hline 5 & Black Stork & Ciconia nigra \\
\hline 6 & White Stork & Ciconia ciconia \\
\hline 7 & Crimson-horned Pheasant & Tragopan satyra \\
\hline 8 & Lesser Florican & Sypheotides indica \\
\hline 9 & Sarus Crane & Garus antigone \\
\hline
\end{tabular}

Table 6 - Protected mammals of Nepal

\begin{tabular}{|c|l|l|}
\hline S.N. & \multicolumn{1}{|c|}{ English name } & \multicolumn{1}{c|}{ Scientific name } \\
\hline 1 & Red Panda & Ailurus fulgens \\
\hline 2 & Gaur & Bos gaurus \\
\hline 3 & Wild Yak & Bos grunniens \\
\hline 4 & Grey wolf & Canis lupus \\
\hline 5 & Hispid Hare & Caprolagus hispidus \\
\hline 6 & Swamp Deer & Cervus duvauceli \\
\hline 7 & Asian Wild Elephant & Elephas maximus \\
\hline 8 & Leopard Cat & Felis bengalensis \\
\hline 9 & Musk Deer & Moschus chrysogaster \\
\hline 10 & Clouded Leopard & Neofelis nebulosa \\
\hline 11 & Great Tibetan Sheep & Ovis ammon \\
\hline 12 & Royal Bengal Tiger & Panthera tigris tigris \\
\hline 13 & Snow Leopard & Uncia uncia \\
\hline 14 & Tibetan Antelope & Pantholops hodgsoni \\
\hline 15 & Gangetic Dolphin & Platanista gangetica \\
\hline 16 & One Horned Rhinoceros & Rhinoceros unicornis \\
\hline 17 & Pygmy Hog & Sus sulvanius \\
\hline 18 & Brown Beer & Ursus arctos \\
\hline 19 & Indian Pangolin & Manis crassicaudata \\
\hline 20 & Chinese Pangolin & Manis pentadactyla \\
\hline & & \\
\hline
\end{tabular}




\begin{tabular}{|l|l|l|}
\hline 21 & Assamese Monkey & Macaca assamensis \\
\hline 22 & Striped Hyena & Hyaena hyaena \\
\hline 23 & Lynx & Felis lynx \\
\hline 24 & Spotted Lingsang & Prionodon pardicolor \\
\hline 25 & Wild Water Buffalo & Bubalus bubalis \\
\hline 26 & Four Horned Antelope & Tetracerus quadricornis \\
\hline 27 & Black Buck & Antilope cervicapra \\
\hline
\end{tabular}

Table 8- Protected Reptiles of Nepal

\begin{tabular}{|c|l|l|}
\hline S.N. & \multicolumn{1}{|c|}{ English name } & \multicolumn{1}{c|}{ Scientific name } \\
\hline 1 & Gharial Crocodile & Gavialis gangeticus \\
\hline 2 & Asiatic Rock Python & Python molurus \\
\hline 3 & Golden Monitor Lizard & Varanus flavescens \\
\hline
\end{tabular}

\section{References}

1. D. D. Bhatt, State of Environment and Biodiversity in Nepal,(1996).

2. S.B., Karmacharya, S.R. Baral, and P. Lacoul (eds), Environment and Biodiversity in the Context of South Asia, Ecological Society (ECOS), Nepal. PP. 26-33.

3. R.P. Chaudhary, Biodiversity in Nepal- Status and Conservation, Tec press Books, Bangkok. (1998)

4. IUCN, An Inventory of Nepal's wetlands, IUCN Nepal, Kathmandu (1996).

5. MOPE state of environment of Nepal, Ministry of population and environment Nepal, Kathmandu, Nepal, (1998)

6. T.C. Majupuria, and R.K Majupuria, Wildlife, National Parks and Reserves. S. Devi Saharanpur, India,(1998)

7. N.Shrestha, Protected Wildlife Species of Nepal. An Introductory Handbook, IUCN (1997).

8. B.N. Upreti, Conservation of Wildlife Resources in Nepal, National Parks and Wildlife Conservation Office, Kathmandu. , (1979).

9. V.K. Thapa, Environmental and Economic Zoology. Durga Books, Kathmandu Nepal (1999).

10. U.K.R. Yadav, Ecology and Physiology, U.K. Publisher, Kirtipur, Kathmandu (2005).

11. P.B. Yonzon, and J.T. Heinen, Nepal's Biodiversity and Protected Areas, the 1997 Protected Areas Management, Workshop of the National Biodiversity Action Plan, Kathmandu, Nepal, (1997). 